Volume 5, Issue 1 (2016) 1-19| Published online, 27 February 2017

The publication of the JEOD is supported by the Autonomous Province of Trento, Italy

\section{AUTHOR}

BRUNO JOSSA

Department of Economics

University of Naples, "Federico II"

bruiossa@unina.it

\title{
On the Advantages of a System of Labour-managed Firms
}

\section{ABSTRACT}

This paper offers an outline of a large body of economic literature which discusses the advantages of a system of employee-managed firms: the disempowerment of capitalists thanks to the suppression of their right to make decisions in cooperative firms; appreciable efficiency gains from worker involvement in production processes; a softer competitive regime and small risks of insolvency; an end to external firm control and, consequently, to the sway of multinational corporations; reduced monopoly building; a socially determined income distribution pattern and economic efficiency gains from a lesser need for state intervention.

\section{KEY-WORDS}

PRODUCER COOPERATIVES; SOCIALISM; HISTORICAL MATERIALISM; ECONOMIC DEMOCRACY; WORKER CONTROL

JEL Classification: B5; P2; P50; P13 | DOI: http://dx.doi.org/10.5947/jeod.2016.001 


\section{Introduction}

This paper examines some of the main advantages of a system of employee-managed firms ${ }^{1}$. There is general agreement that the collective benefits of economic democracy stem from the fact that people who are free to pursue their personal interests are happier than those acting at somebody else's command. And as the power to make business decisions is vested in a small number of persons in any firm, the relevance of this point can hardly be overrated.

Since most of these points are covered in a large body of literature, our analysis will be restricted to those advantages which can be rated as the true strong points of such a system: gains in labour productivity relative to capitalistic businesses; the production of finer human beings than those living in capitalistic systems; the abolition of external firm control; slower monopoly-building; remote bankruptcy risks; a socially determined income distribution pattern and a reduced need for state intervention in the economy.

Although the disempowerment of capital is arguably the main advantage of worker-control, it need not be dwelt on in detail since it is directly implied in its definition: due to the suppression of the "one share, one vote" principle, in a system of producer cooperatives firms are managed in accordance with democratically passed resolutions.

Economic democracy can be "engineered" in dual fashion: through a parliamentary act suppressing wage labour by operation of law or, better still, by enforcing policies targeted towards furthering a gradual, but steady growth of the producer cooperative sector. In both these cases, economic democracy is a "merit good" (see Musgrave, 1958).

\section{Marshall's idea of the cooperative firm as an agent moulding character}

Discussing the impact of economic organisation on character, Alfred Marshall wrote that more than by any other influences, excepting only religious ideals, a man's character is moulded by his every-day work and by the material resources he thus produces, and that "the two great forming agencies of the world's history have been the religious and the economic" (Marshall, 1890: 1).

An even more significant excerpt from a further study reads as follows: "Social science or the reasoned history of man, for the two things are the same, is working its way towards a fundamental unity; just as is being done by physical science, or, which is the same thing, by the reasoned history of natural phenomena. Physical science is seeking her hidden unity in the forces that govern molecular movement: social science is seeking her unity in the forces of human character" (Marshall, 1897: 299-300) ${ }^{2}$.

\footnotetext{
1 This point was addressed in an earlier paper, see Jossa (2010).

2 While it is true that "personality is the result of social relationships" (Heller, 1980: 51), it seems fairly obvious that social science must mainly focus on the agents that shape human personality.
} 
The idea that human character is not given from the outset, but is thoroughly shaped by the environment and its economic structure underlies many of Marshall's writings. For instance, in a comparatively early one we read that we scarcely realise "how subtle, all pervading and powerful may be the effect of the work of man's body in dwarfing the growth of man" (Marshall, 1873: 105-106). In the Principles, on the subject of the relative importance of the main two factors in world history, Marshall states that the influence of religious motives, though probably more intense, rarely extends over as large a part of life as economic factors do. Economic motives, he argues, act themselves out by the day and hour, throughout the greater part of a man's life; for a man's mind is absorbed by matters associated with his business even when he stops working and, as often is the case, sets out to plan future actions" (see Marshall, 1890: 2).

The crucial part played by work in shaping man's character led Marshall to contend that the main task of a social thinker was to suggest institutional reforms capable of furthering the development of ethical motives and the best qualities in man. In Marshall's view, the founding stones of capitalism were the profit motive and individualism, the main springs of "base motives".

This explains why Marshall exalted the ethical motives behind the cooperative movement and its potential for producing fine human beings rather than material goods ${ }^{3}$. In his estimation, cooperation was connoted by high aspirations, as well as the wish to enhance the best in man and educate him to collective action for the achievement of shared ends. Its direct aim was "to improve the quality of man itself" (Marshall, 1889: 228).

This idea returns in a passage from The Economics of Industry, where Marshall and his wife praise the personality of Owen, his "boundless faith in the ultimate goodness of human nature and the possibility to mould noble characters, his deeply-felt desire to bring to the fore the best qualities of men by trusting in them and appealing to their reason” (Marshall and Paley Marshall, 1881: 271-72).

Although Marshall was fully aware that the cooperative movement was bound to come up against major difficulties at the start-up stage, he thought it to hold within itself the seeds of growth, since education helps workers see to their interests and teaches them the moral strength needed for the joint pursuit and attainment of their political goals (Marshall, 1925).

\section{On the advantages of economic democracy}

From the benefits of democratic firms discussed by these major authors in past centuries, we now proceed to the advantages highlighted in more recent theoretical contributions.

The following is a tentative list of the benefits ascribed to democratic firms in the literature:

- the pleasure the partners derive from own-account work;

- wresting power from capitalists;

3 See Marshall (1890: 306; 1889: 228; 1889: 239). 
- a powerful impulse to political democracy;

- major firm efficiency gains from worker involvement in production processes;

- a stop to exploitation and degrading alienated labour;

- the tendency of labour incomes to increase in proportion to boosts in labour and capital productivity;

- more investments in human capital;

- a positive influence on the characters of workers and stronger community feelings;

- $\quad$ softer competition and reduced insolvency risks;

- declines in structural unemployment and the disappearance of classical and Keynesian unemployment;

- marked downward trends in class conflict and wage hikes and the resulting slowdown in inflation;

- improved income distribution;

- $\quad$ an end to external firm control and, hence, to the sway of multinational corporations;

- reduced monopoly building;

- lower environment pollution levels and reduced production of hazardous materials;

- lesser risks of power abuse and fraud;

- economic efficiency gains from a lesser need for state intervention;

- the eclipse of the current paramount role of the economic factor in the evolution of society ${ }^{4}$.

As mentioned above, in this paper our analysis will be restricted to a few inter-related advantages of cooperation, specifically gains in democracy, higher productivity levels, the different role of competition in a system of cooperative firms, remoter bankruptcy risks, fairer income distribution patterns ad a reduced need for state intervention in the economy.

\section{Competition in a system of democratic firms}

As far as competition is concerned, the Scottish 18th century economists who first underscored its importance argued that due to its "magic" effects people pursuing their personal interests would ultimately promote the interests of others as well and, hence, the overall interests of society. This idea is reflected in Adam Smith's well- known saying that "it is not from the benevolence of the butcher, the brewer, or the baker that we expect our dinner, but from their regard to their own interests. We address ourselves, not to their humanity, but to their self-love, and never talk to them of our own necessities, but of their advantages" (Smith, 1776: 17).

The extent to which competition will prove more of less tough depends on ethical, social and government-driven mechanisms. It is well known that Max Weber traced competition to the

\footnotetext{
4 On the subject of the advantages of cooperatives overall, see Birchall (2012). It is worth noting, that Birchall's opinions on producer cooperatives strongly diverge from our approach in this paper.
} 
Calvinistic ethic and that the general public are more supportive of the competitive race in the United States than in other parts of the world.

Marx (1857-58: 333) defined competition as "the free development of the mode of production based upon capital; the free development of its conditions and of its process as constantly reproducing these conditions". In free competition — he argued— "it is capital that is set free, not the individuals. As long as production resting on capital is the necessary, hence the fittest form for the development of the force of social production, the movement of individuals within the pure conditions of capital appears as their freedom".

Further on, he concluded: "thence, on the other hand, the absurdity of regarding free competition as the ultimate development of human freedom, and the negation of free competition as equivalent to the negation of individual freedom and of social production based upon individual freedom. It is merely the kind of free development possible on the limited basis of the domination of capital. This kind of individual freedom is therefore at the same time the most complete suspension of all individual freedom, and the most complete subjugation of individuality under social conditions which assume the form of objective powers, even of overpowering objects—of things independent of the relations among individuals themselves" (Marx, 1857-58: 335).

Taking the cue from Marx, it is possible to argue that the crux of the issue is not so much overly stiff competition, as the fact that competition today appears as "the free development of the mode of production based upon capital". In other words, insofar as it is true that competition in the service of capital is one thing and competition in the best interests of consumers and workers quite another, in a system of democratic firms competition would become a valuable mechanism and, as such, deserve effective protection.

Hence, a major benefit of a producer cooperative system is its potential for reducing competition. As will be argued in more detail in Section 9 below, competition would be cooled off thanks to the lesser insolvency risks faced by cooperatives. A firm whose managers feel tolerably safe from bankruptcy are free to opt for less stiff competition, for instance by granting the partners more free time or reducing workloads in preference to scaling up earnings. No matter how keen, competition under such circumstances would be no ill since the partners might check its effects by deciding it they wish to stand up to it or opt for cuts on their earnings.

In part, the assumed softer competitive regime connoting such a system can be traced to the practice of apportioning the surplus of a cooperative among all the partners. As a rule, the greater earnings flowing from the successful performance of a capitalistic business enterprise accrue to a small number of capitalists. In contrast, cooperatives apportion both earnings and losses among all the partners by definition and this, too, helps scale down competition.

Other authors lay emphasis on the importance of the finding that the pay rates of partners providing equal work inputs do not tend to level out (see Montias, 1976). As the aim of cooperatives is to maximise per capita incomes, these firms have no incentive to recruit workers prepared to accept wage rates below the average pay rate accruing to the existing partners. It is a well-known fact that cooperatives are only interested in recruiting partners whose prospective marginal productivities are above the level corresponding to its average pay-rate. 
This is why workers in cooperatives enjoy a greater and, even more importantly, a different freedom to choose between work and non-work. To clarify this point, it is worth considering that a firm which is not interested in replacing its workers with underbidders is one which knows all too well that even where its pay rates should fall below those of other firms it would barely be at risk of losing its existing workforce. As far as the partners are concerned, they are likely to use this circumstance to their advantage in terms of opting for more free time and fewer working hours.

On closer analysis, though, the situation just described is not devoid of drawbacks. As argued by Rothschild (1986), any one attaining the status of a capitalist and wishing to extend this newly acquired status in time will have no option but to accumulate. He is compelled to do so by the rules of competition governing the historically determined mode of production, and it is these that are the driving force behind his conduct. Accordingly, one adverse effect of a softer competitive regime is to interfere with the dynamic of the economic system and, probably, reduce its potential for growth.

With reference to our line of reasoning in this section, there are reasons for arguing that Marx was perfectly aware that markets are functional to the development of production forces and, therefore, acceptable to the extent they are non-capitalistic in nature, and that this assumption authorises Marxists to lay in a comparable claim. On closer analysis, competition is to be upheld so long as it is not excessively tight; in other words, competition has its benefits and whenever it is kept bland in order to reduce insolvency risks its benefits are redoubled (as will be argued in more detail further on).

\section{The labour productivity edge on capitalistic businesses}

From Gramsci's perspective, for workers' councils to emerge, each worker "must have gained an awareness of his place within the economy. First of all, he must have felt part of an elementary unit or team and must have realised that technical upgrades to machinery and equipment reshape relationships with engineers: less and less dependent on the engineer, his one-time master, the worker must have gained in autonomy and acquired the ability to self-govern himself" (Gramsci 1919-1920: 81)5.

The production modes that arose at various stages of world history, from slavery to capitalism, had one thing in common: workers were stripped of the output of their labour since the benefits of their effort were reaped by others. In other words, over the span of history the best energies of workers have been "wasted" for want of just those incentives that would have induced them to engage in work to the best of their abilities.

5 In Gramsci's mind, a social group aspiring to power must develop leadership abilities well before its takeover (Gramsci, 1975). 
The same does not apply to the members of a producer cooperative, whose title to appropriate the earnings from their work and responsibility for the firm's operations are strong inducements to streamline production and increase output.

If Gintis is right when he argues that "the labour forthcoming from a worker depends, in addition to his/her biology and skill, on states of consciousness, degree of solidarity with other workers, labour market conditions and the social organization of the work process" (Gintis, 1976: 37), an additional strong point of a cooperative system is a work organisation model which fosters mutual solidarity while allowing the partners to make their private utility calculations. And provided it is true that worker solidarity is a salient feature of cooperatives, it seems possible to argue that these firms will hardly be appreciably affected by problems arising in connection with the "moral hazard in teams" issue.

Two additional reasons accounting for the higher labour productivity rates of cooperative firms include greater focus on human capital building and less frequent dismissals. Indeed, risks of dismissal act as a disincentive to working towards the success of the firm and interfere with interpersonal relations.

Other authors endorse the opposite view, i.e. that average work incomes in cooperatives fall short of those recorded in capitalistic business enterprises. Their argument is that the powerful stimulus stemming from the link between the marginal inputs of workers in capitalistic firms and their pay rates is abated in cooperatives since incomes there are strictly dependent on the way the surplus is apportioned among the partners.

In addition to this, the assumed productivity edge of cooperatives is said to be backed up by insufficient evidence. Pointing to promotion as an additional powerful stimulus to dedication and to earning the employer's esteem, some theorists contrast this strong point of capital-managed systems with a major drawback of democratic firms: an incentive to shirk inherent in the fact that only a portion of the surplus revenue generated by a partner's greater work input accrues to that partner. In a cooperative of $n$ partners assigned to equal tasks this portion is but $1 / n$-which means that incentives to production increase in an inverse proportion to the size of a workercontrolled firm.

Even the above-mentioned impulse to worker solidarity is said to generate the awkward effect of inducing hard-working staff members to slow down their rates of work for fear of embarrassing their fellow-workers (for this argument, see Prandergast's 1999 review of the literature on the perverse effects of incentives and Tortia 2008a and 2008b).

At the other end of the spectrum are authors such as Meade (1972), Blumberg (1968), Conte (1982) and others who argue that worker involvement in corporate decision-making may increase motivation even in larger cooperatives and, hence, lead to major productivity gains.

6 Borrowing Hirschmann's terminology (Hirschmann, 1982), it is possible to argue that positive productivity effects may flow from the prioritisation of "voice" over "exit" as the favourite mode of action (see Barreto, 2011). 
The productivity effect of worker involvement was confirmed by the findings of the wellknown experimental project of the Elton Mayo school and, more recently, by a number of empirical researches ${ }^{7}$.

Conflicting results are reported in Hollas and Stansell (1988) and Faccioli and Fiorentini (1998). These two authors maintain that cooperatives are outperformed by capital-managed firms and a comparative analysis of capital-versus worker-controlled firms by Estrin points to a negligible productivity differential when headcount is used as a proxy of labour input and a considerable underperformance of cooperatives when the total hours worked by blue collars are used as a measure of labour input (see Estrin, 1991) ${ }^{8}$.

\section{Income distribution in democratic firms}

The productivity gains associated with cooperation are likely to boost worker incomes above the levels prevailing in capitalistic systems. The question is the following: will income distribution prove to be more or less fair?

As is well known, in the theoretical producer cooperative model the profits reported by the firm are apportioned among the worker-partners based on "coefficients", i.e. pre-fixed percent shares which are centrally determined (and which in individual firms may be adjusted to remunerate some of the workers for more qualified production inputs). And there are reasons to assume that the socially determined distribution pattern substituted for the current market-determined pattern will bring about a fairer social order (see Castoriadis, 1975).

The "sacrifice-based criterion" is a socially determined distribution method that was originally theorised by Albert and Hahnel in numerous essays and subsequently analysed and discussed, among others, by Panayotakis (2009). In our estimation, though, this criterion should at least be complemented with the principle that each individual is to be accountable for the actions and tasks associated with his/her position.

In a worker-controlled firm system, differences in pay levels will be observed within one and the same cooperative and between different firms. Intra-firm income differences produced by the

\footnotetext{
7 See of Jones and Backus (1977); Bellas (1972); Thomas and Logan (1982); Defourny, Estrin and Jones (1985); Estrin, Jones and Svejnar (1987); Bartlett et al. (1992); Levine and Tyson (1990); Sterner (1990); Weitzman and Kruse (1990); Defourny (1992); Estrin and Jones (1992; 1995); Craig and Pencavel (1995); Doucouliagos (1995); Levine (1995); Gui (1996); Ben-Ner, Hahn and Jones (1996); Tseo et al. (2004) and Tortia (2008a).

8 For rather ambiguous results, see Fitzroy and Kraft (1987) and Berman and Berman (1989). Noticeable surveys of this research area include Jones and Pliskin (1991) and Bonin, Jones and Putterman (1993). On closer analysis, though, since the organisational patterns developed by cooperatives before the rise of economic worker control theory depart from the theoretical model to the point of impinging upon labour productivity, it is fair to admit that these surveys are not directly relevant to our approach in this paper.
} 
application of centrally fixed coefficients are socially determined by definition, while the higher pay levels granted to certain categories of workers in exchange for special work inputs should be fixed by the workers themselves at their meetings. In this case, as the workers must have regard to the conditions prevailing in the market, it is more appropriate to say that the resulting coefficients are socially determined just in part, since the social essence of the decisions made by the government on the one hand and by the partners on the other is attenuated — though not entirely nullified—by external market pressures.

Are there grounds for assuming that socially determined distribution coefficients will help reduce inequality?

In point of fact, supply and demand do not obey the same rationale. Whereas demand for labour fluctuates in accordance with the conditions prevailing in markets and with corporate requirements (firms hire fresh workers according to need), supply is not solely determined by market factors, varies over considerably longer time spans and is therefore much less volatile. Accordingly, the prices of the production factors are not determined by the law of supply and demand, as are those of commodities. In a system of cooperative firms, Krugman wrote (2007: 7) that "institutions, norms, and the political environment matter a lot more for the distribution of income" and "impersonal market forces matter less" than economic manuals might lead you to believe (see also, inter alii, Fleetwood, 2006 and Di Quattro, 2011).

Let us assume that the distribution coefficients of a cooperative system are determined by the social choices made by parliament irrespective of the conditions prevailing in markets. A priori, there is no evidence to back up the assumption that a socially determined distribution pattern, once put in place, would level out demand and supply for any category of workers.

But what would happen in a cooperative system in the event of disequilibrium in a single labour market?

When supply for a given job description exceeds demand, firms will be able to recruit personnel with the most suitable qualifications and the long-term unemployed will have no way out but to switch to different jobs. A time series analysis of labour market trends has shown that young people in search for a first job tend to shun those qualifications for which supply systematically exceeds demand and that even in times of excess labour demand firms have difficulty in finding workers with the requisite qualifications. In the long run, however, the market develops its natural response, in terms of inducing the unemployed to choose those job descriptions for which employment prospects are greatest.

In point of fact, due to the combined effects of the educational system and the practice of recruitment by means of competitive examinations such spontaneous market responses will not entirely cancel the socially determined nature of distribution. By its very nature, this recruitment system is a tool that balances out labour supply and demand. And the role played by the educational system in determining the professional choices of the young is well known and need not be entered upon here. In many respects, the educational system and recruitment by competitive examination 
are designed to attain the same goal ${ }^{9}$. In other words, if the public hand regulates labour supply in such a way as to determine the desired adjustments to demand, the pay rates of the factors can be fixed at levels that social conscience will perceive as fair $^{10}$. And the social conscience of individuals working in a system where capitalists have no say tends to develop in the direction of egalitarianism.

All this said, it is fair to admit that the above objection is hardly strong enough to reverse the conclusion that distribution will be more egalitarian in a system of cooperatives than it is under capitalism.

Before we conclude our analysis of distribution, it is worth mentioning the weighty objection that workers expected to take all the risks associated with production may not be fully satisfied with incomes fluctuating in accordance with the changing fortunes of their firms (see, for instance, Ben-Ner, 1987; 1988). To refute this objection, it is possible to argue that the best way to organise a democratic firm is to fix the pay rates of the partners at levels enabling the firm to report a profit, to allocate the undivided surplus to a reserve and to use the relevant funds to offset falls in revenues possibly caused by downturns in business.

A closing and fairly obvious observation is that even in situations where distribution coefficients are socially determined, the state would nonetheless be called upon to play a part, for example by using taxation, fiscal incentives and subsidy policies to correct glaring inequalities (just as happens in capitalist systems) $)^{11}$.

Concluding, we cannot subscribe to the widely shared assumption that even in a system of worker-controlled firms the law of markets would necessarily perpetuate those appalling inequalities which to-date, more than ever, afflict humanity (see Derrida, 1993) ${ }^{12}$.

\section{7. Internal control and firm size in a democratic firm system}

One of the reasons why the "one man one vote" principle is a major plus point of a workermanaged firm system is its potential for reducing systematic inter-firm control. The cross holding structure of group companies is, indeed, both anti-democratic and extremely unfair because it

9 The idea that distribution may be socially determined is at the basis of the movement for participatory economics promoted by Albert (see Albert, 2003).

10 Departing from this approach, Miller (1989) maintains that in a self-managed firm system distribution is determined by the market, but that suitable corrective actions by the state might raise its level of social acceptability well beyond that prevailing in capitalist systems.

11 Whereas an interesting book by Dunn (2005) contrasts markets as the domain of egoism with democracy as the domain of equality, out attempt, in this book, has been to show that economic democracy would tend to reduce the sharp inequalities that are typically observed in capitalist systems.

12 The top executives in major US corporations sometimes draw paychecks in hundreds of millions of dollars, 300-400 times the pay of their employees (see Baker, 2012). 
enables holders of relatively small stakes to control large business sectors and creates the assumption for the holding company to appropriate the profits of any of its subsidiaries by simply passing a majority resolution to this effect.

To a large extent, the dark shadow cast over world politics by the business world is one of the effects of the proliferation of multinational corporations, and the growing political power of firms is the main driving force behind the advancement of post-democracy. An additional advantage of an all-cooperatives system is hence the potential of lesser external firm control to sweep away multinational corporations from the business scene ${ }^{13}$.

At this point, it is worth raising the question if less systematic inter-firm control is likely to scale up the sizes of cooperatives above the present-day average size of capitalistic business enterprises.

Vanek laid considerable emphasis on the tendency of cooperatives to keep the size of their firms to scale with those of their production units (Vanek, 1970). As is well known, upon reaching the dimensional optimum of its production unit, a capitalistic company feels encouraged to implement plant enlargements and upgrades on the assumption that this will generate comparable rises in profits; and this is how monopolies arise. In contrast, a cooperative will consider plant upgrades only in connection with the entry of new members and leave per capita incomes roughly unaltered. It is this that accounts for the differences in scale between capitalistic companies and cooperative firms ${ }^{14}$.

In the opinion of Gordon (1976), the main driving force behind the growing industrial concentration levels typical of capitalistic economies is not the prospect of securing economies of scale, but the process he terms "qualitative efficiency": the aim of the ruling class to keep in check the working class and exercise full control over production. Indeed, capital concentration makes for tighter capitalistic control over production and leaves workers less and less scope for opposing employer decisions. It is the typical response of the ruling class to the struggle of labour for fairer income distribution patterns.

The benefits of the lower industrial concentration levels observed in cooperative systems include a downward trend in advertising expenditure (see Steinherr, 1975) and an appreciable drop in transport costs: if nine firms operate in a given industrial sector in place of a single monopolistVanek computed (2006) — the distance to be covered in supplying consumers assumed to be evenly distributed in space will decline by one-third of the previous total.

Hence, the smaller average size of cooperatives versus capitalistic firms results in a number of advantages for a labour-managed firm system. And in Vanek's view this is probably the most important strong point of such a system and, arguably, one whose scope is far from confined to the domain of economic theory (Vanek, 1993).

13 Hence the comment of Crouch (2003) that this insight would have induced first-generation revolutionaries to campaign for the abolition of capitalism.

14 Authors attaching major importance to this characteristic of cooperative firms include Barreto (2011). 


\section{Reduced bankruptcy risks in democratic firms}

As mentioned before, remoter insolvency risks are a major strong point of a system of cooperative firms. As is well known, companies face insolvency when their costs exceed revenues. Hence, the absence of the largest cost item—wages and salaries—would greatly help confine risks of insolvency in a democratic firm system.

An additional argument is relevant in this connection: if the pay rates of a firm fall below the average level for the system, the partners will tend to leave. However, considering the aversion to the entry of outsiders postulated by the theoretical model of cooperatives, finding better-paying jobs will be all but easy. Hence, on occasion the benefits stemming from remoter insolvency risks in an all-cooperatives system may be offset by the need to put up with lower incomes.

On closer analysis, the downward trend in insolvencies is the result of a major difference between capital- and employee-managed firms: in the former, workers take precedence over capital providers since they cash their wages and salaries on a monthly basis; in the latter, the members participate in the "residual" and, although this may be paid out in monthly instalments as well, it is determined after the whole of the firm's costs, including capital charges, have been duly settled.

In other words, it is possible to argue that the remoter bankruptcy risks faced by workerrun firms are the result of the fact that those holding job relations in these firms would cease being privileged creditors entitled to be satisfied before other creditors in the event of bankruptcy proceedings. Since they are partners, these workers carry the risk and limited liability for a company failure on their shoulders.

Our arguments in support of low bankruptcy frequency - we must add-are only relevant to the theoretical cooperative model in which workers earn variable incomes. In actual fact, in most existing cooperatives the members are paid fixed wages and salaries.

In a system where incomes may be zeroed workers must evidently enjoy some measure of protection, but this goal calls for state intervention into the economy and is a point on which we will come back further on ${ }^{15}$.

The remote bankruptcy risks of cooperatives are inter-related with equally remote risks of dismissal. As is well known, a cooperative may respond to declining demand by reducing the working hours of its workers instead of laying off part of its workforce. On the one hand, it is this that explains why cooperative firms rarely face bankruptcy even in situations of excess headcount and/or drops in income; on the other, it is possible to argue that the low destaffing levels typical of cooperatives can be traced to the remoter insolvency risks run by such firms. Hence, one advantage flowing from the reduced insolvency risks run by employee-managed firms is to make jobs in cooperatives safer and more lasting.

15 The argument that bankruptcies are an exception among employee-managed firms (also for reasons other than those highlighted in this paper) is supported by empirical evidence (see Ben-Ner, 1988; Stauber, 1989; Dow, 2003). 


\section{State intervention in a system of producer cooperatives}

In conclusion, it is worth raising the question if and how the state should intervene in the economy of a worker-controlled firm system.

Arrow has recently re-emphasised that markets are incompatible with government in any form. Moreover, in an analysis of industrial countries Barro has shown that the redistributive State policies required for each piecemeal extension of democracy, though designed to further such a basic component of democracy as equality, are actually at odds with efficiency (Barro, 1996).

Arrow, Barro argue that any state action requiring tax increases stands in the way of the achievement of a Pareto optimum. In an attempt to back up the theoretical approaches of liberalist academics with experiential data, Barro (op. cit.) mentions an awkward link between slow growth and political freedom that should induce governments to reduce state intervention: in a political freedom index (ranging between 0 and 1) of some 100 countries which had provided their 19601990 data, it was observed that countries with an index value above 0.5 were those where growth was slowest.

As these objections are well argued, they can help us pinpoint some of the plus points of a system of producer cooperatives.

A major finding of economic science is the potential of a perfect-competition system to generate a Pareto optimum within the utilitarian tradition of well-being. On closer analysis, however, a Pareto optimum maximises well-being only with respect to a specific initial distribution of economic resources and within a system to which the "survival assumption" is found to apply. As a result, if we take as a starting point a Pareto-optimal situation, a new situation with a better initial income distribution will improve the well-being of a community. Indeed, this is the reason why governments attempt to improve income distribution.

These reflections suggest a weighty argument in support of a cooperative system. As argued by Stuart Mill, production activities are usually contrasted with income distribution because the former are said to obey mechanical rules, while the latter is thought to be socially determined. Inasmuch as this is true, fairer income distribution patterns can be put in place in two alternative ways: a) by enforcing tax bracket adjustments and, hence, both hampering the free working of markets and preventing the achievement of Pareto optimums; b) by enforcing legislation designed to pave the way for equal access opportunities to the more lucrative professions.

Hence, it is possible to argue that a democratic firm system stripping capital of its power and control rights can bring about a fairer income allocation structure even in the absence of actions designed to modify the taxation system or interfere with the working of markets. Options available to governments include policies with a negligible impact on market mechanisms, for example a reform of the educational system, a well-organised system of competitive examinations to govern recruitment or the enforcement of a well-orchestrated succession tax regime. In overall terms, governments can be expected to shape goal-specific strategies ensuring the implementation of State 
intervention policies capable of improving income distribution without encroaching upon the free working of market mechanisms ${ }^{16}$.

In point of fact, government action is not only aimed to shape more equitable income distribution patterns, but also to scale down risks of "market failures". Especially in a globalised world, unwanted economic crises are sure to be sparked off by the workings of the invisible hand as long as there are markets ${ }^{17}$, but despite the obvious implication that downturns in the economy will continue to be a risk even in markets where capitalists have been ousted from power, there are reasons to assume that such undesirable turns of events would be less frequent than they are in capitalistic systems. Indeed, in a system freed from the control of capitalists the State will find it easier to intervene in the economy for the purpose of fending off crises. The multitude may act as one or as many, and it may become a political agent either by developing unity of will or through the workings of the invisible hand. But such unity of will as is expressed through political majority resolutions is much less forcefully counteracted by the action of markets (the invisible hand) if the markets concerned cease being conditioned by the requirements of capital.

To shed light on additional facets of this problem, a comparative analysis of such antipodal systems as a pure capitalistic market economy and one where the state strives to correct malfunctions is likely to suggest the prima facie conclusion that problems can be readily handled if "market failures" are exceptional occurrences and State action can hence be confined to a minimum. In point of fact, it is widely held that market failures are the rule and that massive intervention by a state bureaucracy may generate even grimmer inefficiencies than those self-generated by the market. This poses a need to establish if, and to what extent, a system of producer cooperatives would actually be in a position to outperform capitalistic markets in terms of averting, or at least remedying, the typical failures of a system driven by the private profit motive only. Experience has taught that many issues likely to degenerate into classical market or State failures (dismissals, excess or ineffectual work input control, environment-averse actions, etc.) can be effectively tackled by communities. As these, contrary to the State or markets, have crucial information about the needs and abilities of their members (see Bowles and Gintis, 2002), near-community organisations such as producer cooperatives might take the place of the State or supplement its action in a wide range of situations and reduce the need for public intervention. In overall terms, a democratic firm system where capitalists have been stripped of power is able to tackle most of the causes of market failures even in the absence of state intervention.

\footnotetext{
16 The persuasion that the legal "superstructure" of the bourgeois state was a historical necessity induced Marx to argue that no alternative formal criterion for the distribution of property was likely to outperform it even at the early stages of a communist system (see Zolo, 1974). In this connection, Galgano della Volpe wrote: "As long as a state—albeit a democratic one such as a socialist state-does exist, and as long as there is a social order organised in accordance with the criterion of the distinction between governors and governed, there is no way of deflecting from the basic principle that a limit is to be placed on the power that the state should be allowed to wield over the citizens" (Della Volpe, 1964: 47).

17 This is true despite the creation of the Group of Eight following the epoch-making admission of China and India as additional members.
} 
Inasmuch as this is true, the State would be called upon to intervene in the economy even in a democratic firm system, but its intervention would be less pervasive than it tends to-and mustbe at the present day.

Concluding, a considerable advantage of a cooperative firm system is its potential to further the smooth working of markets thanks to a lesser need for state action.

An additional issue requires discussion at this point. A well-known Italian theorist of the cooperative movement has written: "for my part, I think that the policy of granting benefits to cooperatives is in contrast with the very nature of producer or other cooperative firm models because the relevant costs would ultimately be borne by taxpayers or consumers" (Valenti, 1901: 526).

Is this objection to the point?

Several authors have provided empirical evidence to back up their claim that democratic institutions foster growth. Firstly, they argue that democracy is an enabler of economic growth because its impulse to the circulation of information scales down uncertainty among the general public and favours an awareness of the need for, and effectiveness of State intervention under certain circumstances. An additional claim is that democracy facilitates the accumulation of social capital in terms of developing civic virtues, specifically the ability of the citizens to gain a correct appreciation of the general interest and work towards its achievement. A third claim is that the potential of democracy to reduce inequality impresses further impulse on the development of civic virtues ${ }^{18}$.

\section{Conclusion}

In Musgrave's approach (see Musgrave, 1986), a commodity is classed as a merit good (as opposed to a demerit good) if its production is concordantly rated as beneficial both by its direct users and by the community at large. Accordingly, each newly-founded democratic firm can be categorised as a merit good if it generates benefits for its workers, strips capitalists of their power through the enforcement of the "one man one vote" principle, helps cool down inflation, positively influences the personalities of its members and produces any of the additional advantages discussed in this paper.

The categorisation of the democratic firm as a merit good explains why a wait-and-see policy would be a mistake. In a "free competition" context, cooperatives might fail to assert themselves in their own right and lose out to capital-managed businesses because entrepreneurs planning to set up new firms or reorganising existing ones have little incentive to opt for the cooperative form. Inasmuch as this is true and if democratic firms are actually merit goods, the task of furthering their growth cannot be left to private initiative.

18 See Hall and Jones (1999), Acemoglu, Johnson and Robinson (2002); Rodrik, Subramanian and Trebbi (2002) and Zamagni (2008). 
Deploring the narrow scope of a great many policy decisions, Rawls remarked that efficiency considerations are but one, and often a relatively minor basis of decision, spoke out against the tendency of society to "acquiesce without thinking in the moral and political conception implicit in the status quo or leave things to be settled by how contending social and economic forces happen to work themselves out" (Rawls, 1971: 229), and expressed the hope that specialists in economic policy would at long last broaden their horizons (op. cit.).

Concluding, as soon as cooperatives are categorised as merit goods, it follows quite naturally that any government, whatever its political-economic orientation, should make it its task to further the growth of a democratic firm system by enforcing tax or credit benefits for this purpose.

On this point, though, Dow (2003) has objected that nothing can prevent sceptics from arguing that the sheer level of social spending that would be required to fund the growth of the cooperative movement is barely commensurate with the benefits that can be expected from such a policy ${ }^{19}$.

\section{References}

Acemoglu, D., Johnson, S. \& Robinson, J. (2002). Reversal of Fortune: Geography and Institutions in the Making of Modern World Income Distribution, The Quarterly Journal of Economics, 117(2): 1231-1294. DOI: https://doi. org/10.1162/003355302320935025

Albert, M. (2003). L'economia partecipativa. Roma: Datanews.

Barreto, T. (2011). Penser l'entreprise coopérative: au-delà du réductionnisme du mainstream, Annals of Public and Cooperative Economics, 82(2): 187-216. DOI: https://doi.org/10.1111/j.1467-8292.2011.00436.x

Barro, R.J. (1996). Democracy and Growth, Journal of Economic Growth, 1: 1-27. DOI: https://doi.org/10.1007/ BF00163340

Baker, D. (2012). Getting Radical with Markets, Review of Radical Political Economics, 44(3): 374-379. DOI: https://doi. org/10.1177/0486613412438838

Bellas, C. (1972). Industrial Democracy and the Worker-Owned Firm: a Study of Twenty-one Plywood Companies in the Pacific Northwest. New York: Praeger.

Ben-Ner, A. (1987). Comparative empirical observations on worker-owned and capitalist firms, International Journal of Industrial Organization, 6(1): 7-31. DOI: https://doi.org/10.1016/0167-7187

Ben-Ner, A. (1988). The Life-cycle of Worker-owned Firms in Market Economies: a Theoretical Analysis, Journal of Economic Behavior and Organization, 10: 287-313. DOI: https://doi.org/10.1016/0167-2681

Ben-Ner, A., Han, T. and Jones, D.C. (1996). The Productivity Effects of Employee Participation in Control and in Economic Returns: a Review of Empirical Evidence. In: U. Pagano \& R. Rowthorn (Eds.), Democracy and Efficiency in the Economic Enterprise. London: Routledge, pp. 209-244.

Berman, K.V. \& Berman, M.D. (1989). An Empirical Test of the Theory of the Labour-Managed Firm, Journal of Comparative Economics, 13(2): 281-300. DOI: https://doi.org/10.1016/0147-5967(89)90005-X

Birchall, J. (2012). The Comparative Advantages of Member-owned Businesses, Review of Social Economy, 70(3): 263294. DOI: https://doi.org/10.1080/00346764.2011.632326

19 Jacobsson, Johannesson and Borgquist (2007) have argued that the concept of merit good, though well-established within economic science, lacks a sound theoretical basis. 
Blumberg, P. (1968). Industrial Democracy. The Sociology of Participation. London: Constable.

Bonin, J.P., Jones, D.C. \& Putterman, L. (1993). Theoretical and Empirical Studies of Producer Cooperatives: Will the Twain Ever Meet? Journal of Economic Literature, 31: 1290-1320.

Bowles, S. \& Gintis, H. (2002). Social Capital and Community Governance, Economic Journal, 112: 419-432. DOI: https://doi.org/10.1111/1468-0297.00077

Castoriadis, C. (1975). L'institution imaginaire de la société. Paris: Le Seuil.

Conte, M.A. (1982). Participation and Performance in U.S. Labour-managed Firms. In: Jones, D.C. \& Svejnar, J. (Eds.) (1995). Advances in the Economic Analysis of Participatory and Labor-Managed Firms, vol. IV, Greenwich, CT: JAI Press.

Craig, B. \& Pencavel, I. (1995). Participation and Productivity: a Comparison of Worker Cooperatives and Conventional Firms in the Plywood Industry, Brookings Papers: Microeconomics, I: 121-174. DOI: https://doi. org/10.2307/2534773

Crouch, C. (2003), Postdemocracy. Cambridge, UK: Polity Press.

Defourny, J. (1992). Comparative Measures of Technical Efficiency for 500 French Workers' Cooperatives. In. D.C. Jones \& J. Svejnar (Eds.), Advances in the Economic Analysis of Participatory and Labor-Managed Firms, IV: 27-62. Greenwich, CT: JAI Press.

Defourny, J., Estrin, S. \& Jones, D.C. (1985). The Effects of Workers' Participation on Enterprise Performance, International Journal of Industrial Organization, 3(2): 197-217. DOI: https://doi.org/10.1016/0167-7187

Della Volpe, G. (1964). Rousseau e Marx, IV edit. Roma: Editori Riuniti.

Derrida, J. (1993). Spettri di Marx, It. transl. 1994. Milano: Raffaello Cortina Editore.

Di Quattro, A. (2011). Market Socialism Is not Market Capitalism. Remarks on Robin Hahnel's "Theory of Justice", Review of Radical Political Economics, 43(4): 523-539. DOI: https://doi.org/10.1177/0486613411412533

Doucouliagos, C. (1995). Worker Participation and Productivity in Labor-Managed and Participatory Capitalist Firms: a Meta-Analysis, Industrial and Labour Relations Review, 49(1): 58-77. DOI: https://doi. org/10.1177/001979399504900104

Dow, G. (2003). Governing the Firm; Workers' Control in Theory and Practice. Cambridge: Cambridge University Press. DOI: https://doi.org/10.1017/CBO9780511615849

Dunn, J. (2005). Il mito degli uguali. La lunga storia della democrazia, It. transl., 2006. Milano: Egea.

Estrin, S. (1991). Some Reflections on Self-Management, Social Choice and Reform in Eastern Europe, Journal of Comparative Economics, 15(2): 349-366. DOI: https://doi.org/10.1016/0147-5967(91)90093-9

Estrin, S. \& Jones, D.C. (1992). The Viability of Employee-Owned Firms: Evidence from France, Industrial and Labor Relations Review, 45(2): 323-338. DOI: https://doi.org/10.1177/001979399204500209

Estrin, S., Jones, D.C. \& Svejnar, J. (1987). The Productivity Effects of Worker Participation: Producer Cooperatives in Western economies, Journal of Comparative Economics, 11(1): 40-61. DOI: https://doi.org/10.1016/0147-5967

Faccioli, D., \& Fiorentini, G. (1998). Un'analisi di efficienza comparata tra imprese cooperative e for profit. In: G. Fiorentini \& C. Scarpa (Eds.), Cooperative e mercato. Roma: Carocci.

Fitzroy, F.R. \& Kraft, K. (1987). Cooperation, Productivity and Profit Sharing, The Quarterly Journal of Economics, 102: 23-36. DOI: https://doi.org/10.2307/1884678

Fleetwood, S. (2006). Re-thinking Labour Markets: a Critical Realist-Socioeconomic Perspective, Capital \& Class, 30(2): 59-89. DOI: https://doi.org/10.1177/030981680608900103

Gintis, H. (1976). The Nature of Labor Exchange and the Theory of Capitalistic Production, Review of Radical Political Economics, 8(2): 36-54. DOI: https://doi.org/10.1177/048661347600800203

Gordon, D.M. (1976). Capitalist Efficiency and Socialist Efficiency, Monthly Review, 24: 19-36. DOI: https://doi. org/10.14452/MR-028-03-1976-07_3 
Gramsci, A. (1919-1920). L'ordine nuovo. Torino: Einaudi.

Gramsci, A. (1975) Quaderni del carcere. Edizione critica dell'Istituto Gramsci, V. Gerratana (Ed.). Torino: Einaudi.

Gui, B. (1996). Is there a Chance for the Worker-managed Form of Organization? In: U. Pagano \& R. Rowthorn (Eds.), Democracy and Efficiency in the Economic Enterprise. London: Routledge, pp. 164-183. DOI: https://doi. org/10.4324/9780203011416.ch9

Hall, R. \& Jones, C. (1999). Why do Some Countries Produce So Much More Output per Worker than Others?, The Quarterly Journal of Economics, 114(1): 83-116. DOI: https://doi.org/10.1162/003355399555954

Heller, A. (1980). Per cambiare la vita. Intervista di Ferdinando Adornato. Roma: Editori Riuniti.

Hirschman, A.O. (1982). Rival Interpretations of Market Society: Civilizing, Destructive or Feeble? Journal of Economic Literature, 20: 1463-1484.

Hollas, D. \& Stansell, S. (1988). An Examination of the Effect of Ownership Form on Price Efficiency: Proprietary, Cooperative, and Municipal Electric Utilities, Southern Economic Journal, 50: 195-205. DOI: https://doi. org/10.2307/1059107

Jacobsson, F., Johannesson, M. \& Borgquist, L. (2007). Is Altruism Paternalistic? Economic Journal, 117: 761-781. DOI: https://doi.org/10.1111/j.1468-0297.2007.02049.x

Jensen, M.C. \& Meckling, W.H. (1979). Rights and Production Functions: an Application to Labor-managed Firms and Codetermination, Journal of Business, 52: 469-502. DOI: https://doi.org/10.1086/296060

Jones, D.C. \& Backus, D.K. (1977). British Producer Cooperatives in the Footwear Industry: an Empirical Evaluation of the Theory of Financing, Economic Journal, 87(347): 488-510. DOI: https://doi.org/10.2307/2231555

Jones, D.C. \& Pliskin, J. (1991). The Effects of Worker Participation, Employee Ownership and Profit Sharing on Economic Performance: a Partial Review. In: R. Russel \& V. Rus (Eds.), International Handbook for Participation in Organisations II. Ownership and Participation. Oxford: Oxford University Press, pp. 43-63.

Jones, D.C. \& Svejnar, J. (Eds.) (1995). Advances in the Economic Analysis of Participatory and Labor-Managed Firms, vol. IV, Greenwich, CT: JAI Press.

Jossa, B. (2010). A Few Advantages of Cooperative Firms, Studi Economici, 65.

Krugman, P. (2007). La coscienza di un liberal, It. transl., 2008. Bari: Laterza.

Levine, D.J. (1995). Reinventing the Workplace. How Business and Employees Can Both Win. Washington DC: Brookings Institution.

Levine, D.J. \& Tyson, L. (1990). Participation, Productivity and the Firm's Environment. In: A. Blinder (ed.), Paying for Productivity: A Look at the Evidence. Washington DC: Brookings Institution, pp. 183-244. DOI: https://doi. org/10.2307/41166630

Marshall, A. (1873). The future of the working class. Reprinted in: A. Marshall \& A.C. Pigou (Eds.) (1925), Memorials of Alfred Marshall. London: Macmillan.

Marshall, A. (1889). Cooperation. Reprinted in: A. Marshall \& A.C. Pigou (Eds.) (1925), Memorials of Alfred Marshall. London: Macmillan.

Marshall, A. (1890). Principles of Economics. (First ed.). London: Macmillan.

Marshall, A. (1897). The Old Generation of Economists and the New. Reprinted in: A. Marshall \& A.C. Pigou (Eds.) (1925), Memorials of Alfred Marshall. London: Macmillan. DOI: https://doi.org/10.2307/1882124

Marshall, A. (1925). Memorials of Alfred Marshall, ed. by A. C. Pigou, Macmillan, London.

Marshall, A. \& Paley Marshall, M. (1881). Economics of Industry. London: Macmillan.

Marx, K. (1857-58). Economic Manuscript 1857-58. In: K. Marx \& F. Engels, Collected Works. London: Lawrence \& Wishart.

Meade, J.E. (1972). The Theory of Labour-Managed Firms and of Profit Sharing, Economic Journal, 82, March, Supplement, pp. 402-428. 
Miller, D. (1989). Market, States and Community. Oxford: Clarendon Press.

Montias, J.M. (1976). The Structure of Economics Systems. New Haven: Yale University Press.

Musgrave, R.A. (1958). On Merit Goods. In: R.A. Musgrave, Public Finance in a Democratic Society. Collected Papers of Richard A. Musgrave, vol. I. Brighton: Wheatsheaf Books.

Musgrave, R.A. (1986). Public Finance in a Democratic Society. In: Collected Papers of Richard A. Musgrave, vol. I, Brighton: Wheatsheaf Books.

Panayotakis, C. (2009). Individual Differences and the Potential Tradeoffs between the Value of a Participatory Economy, Review of Radical Political Economics, 41(1): 23-42. DOI: https://doi.org/10.1177/0486613408324407

Prandergast, C. (1999). The Provisions of Incentives on Firms, Journal of Economic Literature, 37: 7-63.

Rawls, J. (1971). A Theory of Justice. Cambridge MA: Harvard Economic Press.

Rodrik, D., Subramanian, A. \& Trebbi, F. (2002). Institutions Rule: the Primacy of Institutions over Geography and Integration in Economic Development, NBER working papers, no. 9305.

Rothschild, K.W. (1986). Capitalist and Entrepreneurs: Prototypes and Roles. In: Wagener, H. J. \& Drukker, J.W. (1986). The Economic Law of Motion of Modern Society, Cambridge: Cambridge University Press.

Smith, A. (1776). Indagine sulla natura e le cause della ricchezza delle nazioni, It. transl. 1973. Milan: ISEDI.

Stauber, L.G. (1989). Age-dependence and Historical Effects on the Failure Rates of Worker Cooperatives. An Eventhistory Analysis, Economic and Industrial Democracy, 10(1). DOI: https://doi.org/10.1177/0143831X89101004

Sterner, T. (1990). Ownership, Technology and Efficiency: an Empirical Study of Cooperatives, Multinationals, and Domestic Enterprises in the Mexican Cement Industry, Journal of Comparative Economics, 14(2): 286-300. DOI: https://doi.org/10.1016/0147-5967(90)90073-I

Steinherr, A. (1975). Profit-maximizing vs. Labor-managed Firms: a Comparison of Market Structure and Firm Behavior, Journal of Industrial Economics, 24(2): 97-104. DOI: https://doi.org/10.2307/2097903

Thomas, H. \& Logan, C. (1982). Mondragon, an Economic Analysis. London: George Allen and Unwin.

Tortia E.C. (2008a), Worker Well-Being and Perceived Fairness: Survey-Based Findings from Italy, Journal of SocioEconomics, 37(5): 2080-2094. DOI: https://doi.org/10.1016/j.socec.2007.10.005

Tortia E.C. (2008b). Governance. In M. Demozzi \& F. Zandonai (Eds.), Impresa Sociale di comunità. Strumenti per la creazione e la gestione. Trento: Edizioni31, pp. 177-198.

Tseo, G.K.Y., Hou Gui Sheng, Zhang Peng-Zhu and Zang Libain (2004). Employee Ownership and Profit Sharing as Positive Factors in the Reform of Chinese State-Owned Enterprises, Economic and Industrial Democracy, 25(1).

Valenti, G. (1901). L'associazione cooperativa e la distribuzione della ricchezza. Contributo alla teoria economica della cooperazione. In: Archivio giuridico 'Filippo Serafini', Nuova serie, Modena: Mucchi editore.

Vanek, J. (1970). The General Theory of Labour-Managed Market Economies. Ithaca: Cornell University Press.

Vanek, J. (1993). From Partnership with Paper to Partnership among Human Beings. In. A.B Atkinson (Ed.), Alternatives to Capitalism; the Economics of Partnership. London: Macmillan.

Vanek, J. (2006). The Future, Dynamics and Fundamental Principles of Growth of Economic Democracy, Mimeo.

Weitzman, M. \& Kruse, D.L. (1990). Profit Sharing and Productivity. In Blinder, A., (1990), ed., Paying for Production, Washington D.C.: Brookings.

Zamagni, S. (2008). Sul nesso causale tra economia e sviluppo economico. In A. Quadrio Curzio \& G. Marseguerra (Eds.), Democracy, Institutions and Social Justice. Milano: Libri Scheiwiller.

Zolo, D. (1974). La teoria comunista dell'estinzione dello Stato. Bari: De Donato. 